\title{
Science and social control: the institutionalist movement in American economics, 1918-1947
}

\author{
MALCOLM RUTHERFORD \\ University of Victoria
}

\begin{abstract}
This paper deals with the concepts of science and social control to be found within interwar institutional economics. It is argued that these were central parts of the institutionalist approach to economics as the key participants in the movement defined it. For institutionalists, science was defined as empirical, investigational, experimental, and instrumental. Social control was defined in terms of the development of new instruments for the control of business to supplement the market mechanism. The concepts of science and social control were joined via John Dewey's pragmatic and instrumental philosophy. These ideas provided important links to the ideals of foundations, such as Rockefeller, and thus to access to research funding. Institutionalist concepts of science and social control were, however, displaced after World War II by Keynesian policy and positivist ideas of scientific methodology.
\end{abstract}

Keywords: institutional economics, science, social control, NBER, Brookings, SSRC, Dewey, instrumental philosophy

JEL Classification: B15, B25, B40, B52

I have just completed a book manuscript with a similar title as this paper. The book attempts to pull together the research I have done over the last 12 years on the history of the institutionalist movement, focusing on the period between the two World Wars. A great deal of this research was archival in nature and has appeared, for the most part, as a series of case studies of interwar institutionalism as found in the careers of particular individuals, or as expressed in particular university departments, programs, or research institutes. What the book tries to do is to knit this material together into a narrative account of the institutionalist movement, and, in the process, provide a picture, both in

AUTHOR's NOTE: The research for this paper was supported by research grants from the Social Science and Humanities Research Council of Canada (SSHRC). 
general and in particular, of the nature of the movement and its trajectory over time. What I want to do in this article is to focus in on one of the key points I make about the nature of interwar institutionalism, and to make a number of arguments regarding its significance and ramifications.

\section{DEFINITIONS OF INSTITUTIONALISM}

The issue I want to raise relates to how the institutionalist movement is defined. There are a large number of definitions of institutionalism in the literature, but almost all of these are based on identifying mark(s) suggested by later commentators. These include evolutionism, Darwinism, recognition of power relationships, methodological holism, support of planning, the ceremonial/instrumental dichotomy, and, of course, dissent from orthodoxy. In my own quest for a definition what I did was to begin from an examination of how the group who initially identified with institutionalism defined it themselves. This raises the question of who exactly constituted this group.

Institutionalism is often identified primarily with Thorstein Veblen, or with a founding triumvirate of Thorstein Veblen, Wesley Mitchell, and John R. Commons. Neither of these views stands up to closer examination. When one looks at the group of people most closely involved with the development and promotion of the idea of an identifiable "institutional approach" to economics, the names that come up are Walton Hamilton, J. M. Clark, Walter W. Stewart, Wesley Mitchell, and Harold Moulton, with Hamilton, Clark, and Mitchell the most important of these. Veblen is in the picture but mainly as a source of ideas and not as a prime mover. Commons is not in the picture at all until a few years later (Rutherford 2000).

The term "institutional economics" seems to have been invented around 1916 by those influenced by Thorstein Veblen (either by Robert Hoxie or Max Handman, depending on which story one chooses to believe). The first major use of the term in the literature was by Walton Hamilton at an American Economic Association (AEA) conference session in 1918 (Hamilton 1919). This session also included J. M. Clark, Walter Stewart, and William Ogburn, and its planning had involved Harold Moulton, who had discussed the session with Veblen and Mitchell. In my book I take this AEA session as the founding moment of the institutionalist movement and the group outlined above as the 
founding group. So, the question, now, is how they conceived of what they were attempting to create.

To answer this question one can look at Hamilton's paper "The institutional approach to economic theory", which was intended as a manifesto, the other papers in the same session, particularly Clark's, Stewart's remarks as session Chairman, and a series of papers written by Hamilton, Clark, and Mitchell in the couple of years leading up to the session. ${ }^{1}$ These pieces of work do give a pretty clear idea of what the founders of institutionalism thought they were about.

Institutional economics was presented as an approach that would (i) focus on institutions, (ii) be concerned with "process", (iii) connect with recent work in related disciplines, (iv) utilize more "scientific" methods, and (v) relate to "the problem of control". Each of these requires some elaboration. Institutions are taken as central as it is institutions that both constrain and mold human behavior. Economic behavior is in large part determined by institutions. The reference to "process" implies an understanding that institutions are not static but in a process of change, both internal change and changes brought about by external developments. In Hamilton's words, institutions "refuse to retain a definite content", and this is true of particular institutions and of the "complex of institutions which make up the economic order" (Hamilton 1919, 315). This reference to process does not imply acceptance of any particular theory of institutional change, although the Veblenian idea that institutions lag behind material and technological developments was quite widely adopted. The interest in related disciplines was expressed primarily in terms of an interest in connecting institutional economics to a foundation in a "modern" psychology, but also involved an interest in connecting to recent work in sociology and law. The concern with proper scientific methods was a concern to make economics more empirical and investigational, and to avoid the speculative and untestable nature of much orthodox theorizing. For institutionalists, science meant being concerned with observation and measurement, avoiding unrealistic assumptions, and paying attention to the results of current research in other disciplines.

Finally, that economics should be relevant to the "modern problem of control" became a very central part of the institutionalist creed. There are a number of meanings attached to this. In Hamilton's own paper it is linked to an economics that does not deal in hypothetical worlds, but

\footnotetext{
${ }^{1}$ These pieces of work are discussed in Rutherford 2000.
} 
which concerns itself with "gathering facts and formulating principles necessary to an intelligent handling" of contemporary economic problems (Hamilton 1919, 313). Problems such as labor unrest, business cycles, unemployment, poverty, externalities of various kinds, monopoly, manipulation of consumer wants, sharp practice, resource depletion, and waste and inefficiency, were all attributed to a failure of markets, or "pecuniary institutions" more generally, to control or direct economic activity in a manner consistent with the public interest.

The notion of an economics "relevant to the problem of control" recurs over and over. This idea also relates to the focus on institutions, as if economics is to be relevant to the problem of control it "must relate to the changeable elements in life and the agencies through which they are to be directed" (Hamilton 1919, 313). This involves an understanding of economic institutions as social constructions that are capable of change and of being changed, rather than as natural and immutable. Control is to be exercised though the modification of institutional arrangements. This requires detailed knowledge of institutional arrangements, their interrelations, and of the ramifications of any proposed changes. The aim of "social control", therefore, also relates to the need for a properly scientific approach.

In my view, the particular combination of the ideals of science and social control lay at the heart of institutionalism's early appeal and success. In Hamilton's words, what institutionalism offered was "an invitation to detailed study" and participation in "the intelligent direction of social change" (Hamilton n.d.a; Hamilton 1926). As stated by Dorothy Ross, "what fuelled the institutionalist ambition was an overflow of realism and new liberal idealism that could not be contained by neoclassical practice" (Ross 1991, 411). What the rest of this paper will do is examine in detail the institutionalist conceptions of science and social control, and relate them to some of the reasons for institutionalism's successes in the 1920s and 1930s, and its relative decline in the post World War II period.

\section{INSTITUTIONALISM AND “SCIENCE”}

The idea of science contained within the literature of interwar institutionalism can be illuminated in more detail by considering the writing on this subject by J. M. Clark, Lionel Edie, Wesley Mitchell, and by many of the contributors to Rexford Tugwell's 1924 volume The 
trend of economics (including, George Soule, Tugwell, A. B. Wolfe, and F. C. Mills). ${ }^{2}$

J. M. Clark's notion of what constitutes science and a scientific economics is of particular interest as his own work was far from purely descriptive and he made a number of important theoretical and conceptual contributions. Clark's views of the required procedures in economics were expressed as follows:

Economics must come into closer touch with facts and embrace broader ranges of data than "orthodox" economics has hitherto done. It must establish touch with these data, either by becoming more inductive, or by much verification of results, or by taking over the accredited results of specialists in other fields, notably psychology, anthropology, jurisprudence and history. Thus the whole modern movement may be interpreted as a demand for a procedure which appears more adequately scientific (Clark 1927, 221).

Clark argued for an economics "based on a foundation of terms, conceptions, standards of measurement, and assumptions which is sufficiently realistic, comprehensive, and unbiased" to provide a basis for the analysis and discussion of practical issues (Clark 1919, 280). Relevance to practical issues, accuracy of data, and comprehensiveness, in the sense of not excluding any evidence relevant to the problem at hand, were the characteristics of a scientific approach to economics that Clark frequently stressed (Clark 1971 [1924], 74). He certainly thought of theory as playing a key role, but he saw the aim of theorizing as that of forming hypotheses "grounded in experience" for further study and empirical test, rather than the production of a highly abstract system of laws. Hypotheses must therefore be formulated in terms that allow for empirical verification or refutation (Clark 1971 [1924], 76).

As for the relationship between institutionalism and science, Clark argued that the term institutional economics is a term "used by a group of the younger American economists to define a point of view-one might almost make it coextensive with the scientific point of view-in economic study". This point of view "sets up the ideal of studying the interrelations of business and other social institutions as they are and not through the medium of any simplified abstractions such as are

${ }^{2}$ This section is based on Rutherford 1999. See also Yonay 1998. 
employed by classical, static, and marginal economics" (Clark 1927, 271).

Lionel Edie can be found saying not dissimilar things. He describes institutional economics as "an extension of scientific method in economics", with a special emphasis on the use of recent work in sociology and social psychology to replace the assumption of "independent individual rationality", on the role of empirical investigations of various kinds to verify or disprove theories, modify theories, or suggest new theories "pertinent to the problems confronting us" (Edie 1927, 407-410). In his slightly earlier survey of institutionalist research entitled Economics, principles and problems (1926), Edie outlines the main characteristics of the "new approach" as including the influence of newer historical and anthropological research and the use of psychological presuppositions in line with modern psychology, the rejection of the notion of immutable natural laws and a substitution of a view of economic conduct as governed by institutions, the use of quantitative methods to supplement qualitative, a view of economic generalizations as tentative, and of the nature of hypotheses "to be tested by experimental and statistical science" (Edie 1926, viii).

Many of the essays in the Tugwell volume are replete with the language of "science" (Yonay 1998; Rutherford 1999). George Soule contrasts the confidence that is given to scientific knowledge in the realms of physics and chemistry with the lack of authoritative "tested knowledge" in the area of economics. Classical economics moved too quickly from induction to general conclusion, they "improvised their psychology" and subsequently lost touch with the growth of "scientific psychology" based on "experimental method and quantitative testing". All of this led to the "building up of bodies of economic doctrine which more resembled closed systems of metaphysics than an account of the real world" (Soule 1971 [1924], 359-361). Soule detects, however, a "rapid growth toward maturity" to be found in the desire to "make the science practically useful", accompanied by greater availability of data and the use of quantitative research and statistical methods (1971 [1924], 364).

At Columbia, Tugwell attended lectures given by John Dewey, out of which he developed his idea of "experimental" economics (Tugwell 1971 [1924]; 1982, 157). Tugwell argues that the "assurance of rightness in science" is to be found in the replication of experimental results. In this vein he discusses Newton and Galileo. In Tugwell's words "it is 
sometimes more, sometimes less, difficult to isolate and to demonstrate by experiment the bits of truth that scientists discover; but nothing is accepted as truth unless it can be so demonstrated" (Tugwell 1971 [1924], 386). Social scientists, according to Tugwell, see themselves in "direct line of descent" from natural scientists, the only difference being that the conclusions of social science having to "meet the test of application in a complex going system immediately". Social science must try to "isolate its problems and to devise and use special tools for dispassionate verification" (Tugwell 1971 [1924], 387). These tools include the efforts of specialized research organizations and the use of quantitative and statistical methods.

Tugwell also argues "the truth must be useful; and if science does not help to solve a problem it cannot reach out toward truth" (Tugwell 1971 [1924], 387). This idea allows Tugwell to argue that natural laws in the physical sciences have a different status from the so-called laws of classical economics. Tugwell seems to regard natural laws, even the natural laws of physics, as simply useful generalizations or hypotheses and not as ultimate. However, in the physical sciences natural laws such as the law of gravitation have proven themselves in "innumerable experiments" and in problem solving, while the laws of classical and neoclassical economics have not. Supposed economic laws are often little more than an embodiment of ideology or an expression of dialectical dilettantism (Tugwell 1971 [1924], 393). In Tugwell's words:

Natural law has lost its force in analogous application because so many times events have disproved its premises. There has been a drift toward the substitution of consequences for premises in the search for truth in all fields [...]. Nothing can be taken as ultimate any more. And these facts are the consequences. Theory must have reference to them if it is to be useful (Tugwell 1971 [1924], 394-395).

A. B. Wolfe remarks on the differences of viewpoint between several of the "younger men" but goes on to state that they all "hold that economics ought to be scientific". Wolfe ascribes this growing "demand for a realistic, inductively analytical, non-metaphysical, scientific economics" to the matter-of-fact spirit of the times and a "growing conviction that the older economic theory, whether classical, neoclassical, or marginalistic, is deficient in scientific quality" (Wolfe 1971 [1924], 447). 
According to Wolfe, the main features of the scientific method are (1) unbiased selection of factual data, without "undue limitation of range", and freedom from personal or class interest; (2) hypotheses seen as devices in a trial and error method; (3) all generalizations regarded as tentative; and (4) deductive inferences to be tested by "repeated appeal to experience", and long chains of deductive reasoning to be avoided (Wolfe 1971 [1924], 451). Clearly, Wolfe regarded orthodox economics as seriously deficient in all of these respects. Wolfe, however, did not see science as solely a quest for knowledge for its own sake, but also motivated by ethical ideals and normative standards. He held out the prospect of a "scientific ethics" based on behaviorist psychology and social psychology. A scientific understanding of human nature should "point the way to a fundamental, objectively scientific, ethical norm or ultimate end of life" (Wolfe 1971 [1924], 478).

A high proportion of the institutionalist discussions concerning a scientific economics in the inter-war period contained at least some mention of the importance of quantitative work. In this, the work of Wesley Mitchell, and of those who followed his lead, such as Walter Stewart and F. C. Mills, was central. Mitchell reacted particularly strongly against the speculative, normatively biased, untested, and often untestable nature of existing economic theory. He argued that the social sciences were held in low repute and, given the lack of exactness and certainty of their conclusions, deservedly so. The solution was to imitate the natural sciences in their careful and painstaking work of observation and experiment, systematic analysis, and desire to eliminate normative biases and achieve objective results (Ginzberg 1997; Biddle 1998). Mitchell put the matter as follows:

There seemed to be one way of making real progress, slow, very slow, but tolerably sure. That was the way of natural science [...]. Not the Darwinian type of speculation which was then so much in the ascendant-that was another piece of theology. But chemistry and physics. They had been built up not in grand systems like soap bubbles; but by the patient processes of observation and testingalways critical testing-of the relations between the working hypotheses and the processes observed. There was plenty of need for rigorous thinking, indeed of thinking more precise than Ricardo achieved; but the place for it was inside the investigation, so to speak-the place that mathematics occupied in physics as an indispensable tool. The problems one could really do something with in economics were problems in which speculation could be controlled (Mitchell 1936 [1928], 413). 
Mitchell saw quantitative and statistical work combined with careful policy experiments as the closest approach to the methods of the natural sciences possible in economics. In his attitudes towards science Mitchell was clearly influenced by John Dewey's instrumental approach. Quantitative work in economics required all the trappings of the natural sciences-a "statistical laboratory", research assistants and fieldworkers (Mitchell 1925). This, of course, was the ideal of scientific research that Mitchell embodied in the National Bureau of Economic Research (NBER). Mitchell also talked of experimentation, at least in the form of experiments on group behavior. He recognized some of the difficulties of attempting to apply experimental methods to economics, but argued that they could be mitigated by more reliance on "statistical considerations and precautions" (Mitchell 1925, 31). ${ }^{3}$

A similar emphasis on quantitative and statistical approaches can be found in F. C. Mills's essay "On measurement in economics", again in the Tugwell volume (Mills 1971 [1924]). Mills quotes Lord Kelvin to the effect that without measurement and numerical expression there cannot be a science, and quotes both James Clerk Maxwell and Karl Pearson on the statistical view of nature. For Mills all social relationships do not hold universally or with absolute certainty. In the statistical approach "we forego the searching for sole causes and, instead, seek to measure the degree of association found in experience" (Mills 1971 [1924], 4344). Furthermore, such relationships are not seen as "final formulations of truth" but in a process of development towards higher degrees of probability. Interestingly, Mills finds the statistical conception "in complete agreement with the views of philosophers of the pragmatic school" such as Dewey. Mills quotes with approval Dewey's remarks that generalizations are "not fixed rules [...] but instrumentalities for [...] investigation" and are "hypotheses to be tested and revised by their further working” (Mills 1971 [1924], 45-46). Mills also links a quantitative and statistical economics to the more effective solution of economic problems. Practical problems will be more readily solved "by quantitative study of specific conditions than by the attempt to apply vague generalizations of doubtful validity" (Mills 1971 [1924], 70).

\footnotetext{
${ }^{3}$ For Mitchell, quantitative work was linked to the institutional approach. He rejected the idea that quantitative work would simply complement orthodox theory, as that theory was not stated in terms amenable to statistical attack. Quantitative work would lead to a focus on the patterns of mass behavior that, for Mitchell, were clearly of institutional origin. See Rutherford 1987.
} 
Similarly, Stewart argued that "an adequate analysis of many of our problems can be made only by a union of the statistical method and the institutional approach" (Stewart 1919, 319).

All of this rhetoric of science stands in marked contrast to the neoclassical literature of the time that tended to stress the limited nature of the applicability of natural science methods to economics. ${ }^{4}$ The notion of science apparent in this body of institutionalist writing clearly borrows heavily from John Dewey. Mitchell absorbed Dewey's teaching at Chicago, Hamilton learnt Dewey through the teaching of Charles H. Cooley at Michigan, Stewart went to Columbia for a term to study with Dewey, Mills and Tugwell took Dewey's courses at Columbia. This pragmatic and instrumentalist view of science was broadly empirical with a strong emphasis both on realism of assumptions and on testing of empirical implications.

Testing was not done using econometric techniques, but the implications of theories were compared with the results of empirical and statistical investigations in a variety of less formal ways. Mitchell, in his statistical examinations of the course of business cycles, frequently remarked on the consistency or inconsistency of his findings with various business cycle theories (Mitchell 1913). Morris Copeland tested different views of the quantity theory (pro and con) by drawing out the implications for the leads and lags one would expect to find and then examining the data (Copeland 1929). Hamilton's work on the bituminous coal industry found many buyers and sellers and a relatively homogeneous product, but an industry characterized by "chaos" and not by a stable competitive equilibrium (Hamilton and Wright 1925). Clark examined the effect of overhead costs on the pricing policy of firms, concluding that they resulted in departures from the standard models, and drove such observed phenomena as price discrimination and cutthroat pricing (Clark 1923). Examples such as these could be multiplied.

Moreover, institutionalists saw theories as instruments for both investigation and control, that is, for the solution of both scientific and practical problems. Theories are tested, ultimately, by the results of

\footnotetext{
${ }^{4}$ See Knight 1935 [1924], and Viner 1928, as examples. Knight compared neoclassical economics to "theoretical physics". Henry Moore and his student Henry Schultz attempted to provide neoclassical theory with an empirical component, but with limited success. Within the institutionalist literature, neoclassical theory was seen as overly abstract and "speculative", and frequently untestable or untested. It is also worth noting that Veblen was frequently criticized for similar failings. See Rutherford 1999.
} 
their usefulness as instruments not just for investigation but also as instruments for social control.

\section{INSTITUTIONALISM AND "SOCIAL CONTROL"}

The term "social control" originated in sociology in the 1901 book by Edward A. Ross of that name (Ross 1901). Ross discusses a large number of ways in which societies control the behavior of their members. Social control is the way in which social order is established and maintained. Ross distinguishes between an unplanned spontaneous "natural order" based on a set of social sentiments including sympathy, sociability, sense of justice, and resentment, and a planned and conscious "social order". As societies become more complex the natural order is replaced by a social order, maintained by social controls including public opinion, belief, social institutions, and laws. Social control includes both external incentives and sanctions and the internalization of social norms and values. Thus, the instruments of social control can be either ethical (moral) or political.

Social change, and, in particular, the rapid changes occurring in America with rapid industrialization, required new forms of social control. As has been argued, Ross's Social control is a book that is "manifestly interventionist and anti laissez-faire in its tenor, seeking to contribute to the solution of social problems in order to sustain the progressive direction of social change" (Weinberg, Hinkle, and Hinkle 1969, viii). Franklin Giddings in a review of Ross's book states social control is intended; it "springs from a self-conscious knowledge of factors and tendencies in economic life, and proceeds according to plan" (Giddings 1902). This idea of social control profoundly influenced not only institutional economists but also other social scientists, especially those in sociology and political science.

There is a vast institutionalist literature that utilizes the concept and rhetoric of social control. What I will do here is to examine a small part of this literature: some of Hamilton's writings, J. M. Clark's Social control of business (1926), Dexter Keezer and Stacy May's The public control of business (1930), and the entry "Social control" in the Encyclopaedia of the social sciences written by Helen Everett (1931). Keezer, May, and

\footnotetext{
${ }^{5}$ Other notable examples are to be found in Hamilton and May's The control of wages (1968 [1923]), Sumner Slichter's "The organization and control of economic activity" (1971 [1924]), and Leo Wolman's "The frontiers of control" (1927). A number of Mitchell's essays have a similar theme of "intelligent guidance" (Mitchell 1950 [1936]).
} 
Everett were all students of Walton Hamilton. Although written last we will begin with Everett's entry.

Everett begins by discussing Ross's Social control and notes the existence of both a wider and a narrower sense of the term. The wide sense of social control involves "exploring the forces by which the group molds and shapes the individual"; the narrow sense of it is that of the "active intelligent guidance of social processes" or "the consciously planned guidance of economic processes". She continues:

In America the institutionalist school of economics, whose outstanding figures are Thorstein Veblen, Wesley C. Mitchell and Walton H. Hamilton, has made important use of the concept of social control. Indeed it is perhaps their central organizing principle. The emphasis of the institutionalists is that economic arrangements are man made and susceptible to almost limitless variation. While for most economists the idea of control is like a mechanical bit of apparatus, for the institutionalists it is more of the nature of the guiding formula itself (Everett 1931, 345).

Everett also makes an explicit connection to the work of John Dewey, quoting him saying that "we have attained [...] a certain feeling of confidence; a feeling that control of the main conditions of fortune is, to an appreciable degree, passing into our own hands" (Everett 1931, 348; Dewey 1929, 9).

Hamilton's central argument was that the existing system of social control was inadequate to cope with new economic conditions and problems, and that additional methods of social control had to be devised. Hamilton discusses the development of "modern industrialism" from the pre-capitalist manorial system, a process that included both the development of large scale methods of production, and a complex of institutional developments relating to property and contract, markets, the adoption of pecuniary goals and incentives, the corporate form of organization. This gave rise to what he calls the system of "business control", a system based on the instrumentalities of "the corporation, the pecuniary calculus, and profit making" (Hamilton n.d.b).

The key issue, of course, is the adequacy of this system of control. In the economics textbooks it is competition that is supposed to operate to reconcile the individual pursuit of pecuniary gain with community welfare, but Hamilton consistently argues that competitive theory and the policies that it suggests apply only to an economy of "petty trade". For Hamilton "the fundamental issue stands out in clear cut relief": 
there is a disconnect between the technology of industry and the form of its control. "An economic order in which the productive processes belong to big business and the arrangements for its control to petty trade cannot abide". The task is to "devise a scheme adequate to the direction of great industry. In a world of change a society cannot live on a wisdom borrowed from our fathers" (Hamilton 1932, 593). Hamilton's work on health and the coal industry indicate his willingness to consider new institutional arrangements designed to overcome the particular problems he identified in each case (Rutherford 2005a). He developed a keen interest in law and economics and in what he called "the judicial control of industry", a theme carried on by some of his students.

Keezer and May provide a critical analysis of the attempt to provide for the control of business through the instrumentalities of the antitrust laws, the regulation of enterprises "affected with a public interest", and government ownership and operation. They argue that the anti-trust laws have been ineffective in maintaining competition primarily due to judicial decisions finding that the mere size of an enterprise does not constitute a violation. Similarly, the courts have narrowed the definition of enterprises affected with a public interest to the point where public interest laws have been rendered ineffective in all but a very restricted number of circumstances.

Concern with this doctrine of "affectation with a public interest" and its history before the courts was something also discussed at length by Hamilton (1930), Tugwell (1968 [1922]), and Clark (1926). In the case of public utility regulation Keezer and May find that the court's definition of the valuation of the enterprise upon which a "fair return" is to be calculated had obstructed the possibility of rate regulation in the public interest. ${ }^{6}$ In contrast the barriers to public enterprises, even when established in direct competition to private concerns, are not judicial but political. Public enterprise then, is a "potentially effective form of government control" of business.

Keezer and May argue that an effective system of public control should be able to use all three of the instruments outlined above in much less restrictive ways, that regulators should have access to relevant information, and that the available instruments of control be used flexibly and experimentally. All of this would, however, require

\footnotetext{
${ }^{6}$ The issue of how the courts decided on a fair rate of return was much discussed by those involved in public utility regulation, notably by Bonbright and Hale at Columbia. See Rutherford 2004.
} 
substantial changes to the then existing judicial interpretations of private property rights (Keezer and May 1930, 230-254).

Clark's Social control of business is one of the paradigmatic works of American institutionalism, and the most broad-ranging treatment of the social control issue to be found in the institutionalist literature. Clark's fundamental argument is that it is clear that "industry is essentially a matter of public concern, and that the stake which the public has in its processes is not adequately protected by the safeguards which individualism affords" (Clark 1926, 50). Society, therefore, has ample grounds for interfering with business. Business will, of course, resist controls, and such resistance is not likely to diminish.

The available instruments of control discussed by Clark are the legal framework, particularly laws of private property, contract, and bankruptcy; competition; control by the state; the establishment of standards, for example standards of health and standards of living; and informal controls such as ethical norms or professional codes. The possible grounds for state intervention in the economy are wide. They include public defense, protection of person and property, regulation of common property resources, controlling inheritance and bequest, raising public revenues, prevention or control of monopoly, maintaining the level of competition, protecting the individual where he is not competent to judge or lacks information, problems of agency, providing for victims of change or catastrophe, provision of a social minimum, economic guidance and consumer information, equality of opportunity, "unpaid costs of industry" or externalities, "inappropriable services" or public goods, arms race types of competition and cases where the actions of individuals or firms neutralize each other wasting resources, unused capacity, interests of posterity, and other discrepancies between private and social costs. Clark then discusses various ways of "protecting consumers against exploitation" mostly focused on forms of regulation of prices, but including also public ownership and operation, and other ways of affecting market outcomes either directly or indirectly. "Social control must reckon with the forces of supply and demand, but does not stand helpless before them" (Clark 1926, 459).

It might be added here that the institutionalist interest in social control also extended to macroeconomic policy in the form of anticyclical public works programs and other methods to mitigate cycles and cyclical unemployment. There was an extensive pre-Keynesian institutionalist literature on depressions and unemployment, some 
based heavily on Mitchell's research program on business cycles, and some based on underconsumptionist ideas drawn mainly from J. A. Hobson (Rutherford and DesRoches 2008).

The theme of all of this is clear: existing methods of regulation and control of business in the public interest are inadequate and new forms are required. These new controls may take the form of regulation or of more direct government involvement in the economy. Examples of the types of social control promoted or pioneered by institutionalists include public utility regulation; the creation of regulatory commissions or an administrative approach to the approval or disapproval of business practices; labor legislation of various types, including the promotion of collective bargaining, labor mediation and arbitration; workmen's compensation programs, unemployment insurance, and social security; agricultural price support programs; improved representation of consumer interests; medical insurance programs; and the countercyclical "planning" of public works programs (Clark 1935).

These institutionalist ideals of scientific investigation and social control, and the emphasis they gave to the law as an instrument of social control, provided the basis for the close linkage between institutionalist economists, other progressive social scientists, and legal realists. ${ }^{7}$ The connections between institutionalists and legal realists are particularly noteworthy, but are not surprising given that legal realism was also founded on the ideals of applying empirical scientific methods to the study of law, and the promotion of "pragmatic social reform through legislative change" (Fried 1998, 14).

\section{SCIENCE, SOCIAL CONTROL, AND THE FOUNDATIONS}

The institutionalist ideals of science and social control were shared not only by many other social scientists but also by many of those in charge at the major foundations. This congruence of ideas lay behind the willingness of foundations such as the Laura Spelman Rockefeller Memorial (LSRM) and, later, the Rockefeller Foundation to fund organizations such as the Social Science Research Council (SSRC), the Brookings Institution, and the National Bureau of Economic Research

\footnotetext{
${ }^{7}$ For a discussion of some interdisciplinary linkages between institutionalists and other social scientists and legal realists, see Rutherford 2004. For a discussion of legal realism and institutionalism, see Fried's (1998, 10-15) discussion of Robert Hale as an institutionalist and realist. Hale began in economics at Columbia but moved into the Law School. Columbia had a large contingent of both institutionalists and legal realists. Hamilton moved to Yale Law School in 1928, then the major center for legal realism.
} 
(NBER). The major figures at the SSRC were Charles Merriam, ${ }^{8}$ Mitchell, and Ogburn. The NBER was headed by Wesley Mitchell, and Brookings by Harold Moulton. All of these organizations were heavily institutionalist in orientation.

The most notable development in funding for the social sciences in the interwar period came initially from the program developed by Beardsley Ruml and his staff at the Laura Spelman Rockefeller Memorial Foundation (Bulmer and Bulmer 1981). In 1922, Ruml set out his views in a "general memorandum" that emphasized the importance of the development of social sciences, and, in particular, the "production of a body of substantiated and widely accepted generalizations as to human capacities and motives and as to the behavior of human beings as individuals and groups". The underlying purpose was the generation of social scientific knowledge that could be used for social improvement. Ruml argued that "all who work toward the general end of social welfare are embarrassed by the lack of that knowledge which the social sciences must provide", the situation being as if "physicians were practicing in the absence of the medical sciences" (Ruml 1922, 9-10).

In 1923 Ruml commissioned Lawrence K. Frank to carry out a review of social science research in universities and independent research organizations. Frank was an economist of institutionalist persuasion who had trained at Columbia with Wesley Mitchell. Frank's report deplored the lack of funding for properly scientific social science research, by which he meant work that was "investigational" or "experimental", terminology that reflected the influence of John Dewey. These scientific methods he contrasted with those of speculative theorizing and library based research, the dominance of which had resulted in both the "inertia" of the social sciences and its failure to separate itself from political partisanship (Frank 1923, 20-21). After completing his report Frank joined the staff of the Memorial.

Ruml and Frank came from social science backgrounds and both were concerned with advancing "basic" research that might contribute to the solution of social problems over the longer term. The LSRM supported a conception of social science requiring "not the reading of books and abstract thought" but "realistic" and methodical empirical and quantitative research (Bulmer and Bulmer 1981, 347-348). There was, then, a clear and quite explicit consensus between Ruml and Frank

\footnotetext{
${ }^{8}$ Merriam was a Chicago political scientist. He fully shared Mitchell's emphasis on quantitative social science. For a discussion of the SSRC see Fisher 1993.
} 
at the LSRM and economists such as Wesley Mitchell, and others of similar mind, which worked through the NBER and other organizations to promote a particular concept of "scientific" economics; one that was associated with empirical and quantitative work directed to improved social control. In this manner the major foundations and institutional economists could, and did, form an alliance based on the shared values of an investigative science directed towards improved social control. As argued by Donald Fisher:

What brought the social scientists and the foundations together was the concept of "social control". For sociologists, this concept had become the central theoretical thrust behind their attempts to investigate social problems [...]. Institutional economists like Mitchell used the concept as a means of linking together their efforts to improve upon the mechanisms of competition and the marketplace [...]. The theoretical and the practical merged as these social scientists and foundation officials [...] sought to use social scientific research to solve social problems and thereby increase the degree to which society was socially controlled (Fisher 1993, 58).

This congruence between the major foundations and institutional economics persisted even after the LSRM was merged into the Rockefeller Foundation and Ruml was replaced by Edmund Day and then by Joseph Willits. Both Day and Willits shared the institutionalist view of science and the goal of improved social control (Rutherford 2005b). This was not incidental to the success and position of institutional economics in the 1920s and 1930s.

This relationship was also expressed clearly by Wesley Mitchell. Mitchell was very concerned to keep scientific research separated from political partisanship, because he wanted to protect the NBER from any possible charges of political bias, but he fully accepted that the goal of research was improved social control. In 1936 Mitchell suggested the formation of a National Planning Board, a kind of federally funded NBER, to plan and organize the study of social problems. A planning organization could, "by throwing light upon the consequences that different lines of action would produce", contribute to the "attainment of a more rational scale of social values than now prevails among us" (Mitchell 1950 [1936], 135). The practical application of this point of view can be seen in the NBER involvement in studies such as Recent economic changes in the United States (1929), while Mitchell's linking of 
scientific investigation into consequences to the appraisal of "social values" is a viewpoint that clearly owes much to Dewey's philosophy.

\section{SCIENCE, SOCIAL CONTROL, AND THE DECLINE OF INSTITUTIONALISM}

As we move forward into the late 1930s and 1940s the position of institutional economics changes quite drastically. There are many elements to this changing situation but in the context of the theme developed here those of most importance involve the development of Keynesian economics and its related policy positions, and the widespread adoption within economics of some version of the positivist view of science.

It is sometimes claimed that institutionalism was simply swept away by the arrival of Keynesian economics. Such a picture is far from accurate (Rutherford and DesRoches 2008), but Keynesian economics did pose major challenges, particularly as it apparently provided an effective cure for unemployment through the use of the instrument of fiscal policy. For example, Clark willingly conceded that "certain central problems cannot be successfully handled without the use (which does not imply exclusive reliance) of the income-flow method of analysis of which Keynes's studies are the most prominent form" (Clark 1942, 9).

After World War II, the apparent success of Keynesian macro policy and its connection, both in the UK and in the US, to broader programs of economic reform of a progressive nature, allowed Keynesians to take over the claim to represent effective social control. ${ }^{9}$ The volume The new economics, edited by Seymour Harris (Harris 1948) is dedicated "to those economists who, following the leadership of Lord Keynes, are endeavoring to make of economics a useful tool for the diagnosis and treatment of economic disease" (Harris 1948, v). Harris goes on:

Keynes indeed had the Revelation [...] laissez-faire is outmoded; the excrescences of capitalism must be removed; government control of money, interest, savings, and investment is recommended; but individual liberties to choose occupations, to select goods for consumption, to make profits, should not be impaired (Harris 1948, 5).

Keynesianism also quickly became connected to an empirical component in the form of macro-econometric models. This was critical, as institutionalists could no longer claim to be the primary

\footnotetext{
${ }^{9}$ The objects of Keynesian social control were still narrower than in the institutionalist case.
} 
representatives of empirical economics. Keynesian economics generated a very similar kind of appeal to that generated by institutionalism some decades earlier. Keynesianism seemed to offer exactly that promise of science and social control that institutionalism had held out in the 1920 s and generated a very similar degree of excitement among the younger economists of the time.

As argued above, in the 1920s and 1930s it was institutionalists who made the stronger claims to "science". This situation radically reversed itself in the post-1945 period mainly due to the importation of various positivist ideas of science. Positivism in various forms was brought to the United States by W. V. Quine and Rudolph Carnap, and by the many émigré academics who arrived to escape fascism in Europe. ${ }^{10}$ It is sometimes claimed that institutionalists (and particularly people such as Mitchell) adopted "positivist" ideas, but such claims require care. As Wade Hands has argued:

Yes, pragmatism, like logical positivism, was a "scientific philosophy"; and, yes, both approaches promote the extension of scientific reasoning [...] and, yes, both are broadly "empirical" and concerned with "experience"; but the similarities essentially stop with these basic points. Dewey in particular had a very "latitudinarian" view of the experimental method of science [...] and never exhibited the positivist tendency to view "science" as a narrowly circumscribed endeavor. Dewey was both antiepistemology and anti-foundationalist and certainly never shared the positivist goal of dictating the proper empirical foundation of all scientific knowledge. Perhaps most importantly, he considered the scientific form of life to be social, linked to democracy, and not a subject for armchair philosophizing about the ultimate character of knowledge (Hands 2004, 959).

In the post World War II period institutionalist claims to scientific status were strongly challenged both by the Cowles Commission (Koopmans 1947), and later by Chicago economists such as Milton Friedman (1953). Orthodox economists came very largely to adopt either the logical empiricism of Rudolf Carnap, Carl Hempel, and Ernest Nagel, or Friedman's positivist version of instrumentalism. Logical empiricism emphasizes the "hypothetico-deductive" nature of theories. Theories contain axioms and statements derived from them. The axioms "may refer to either observables or theoretical entities", and the "system is

${ }^{10}$ For discussion of the impact of émigré economists in America see Craver and Leijonhufvud 1987; Scherer 2000; Hagemann 2005; and Mongiovi 2005. 
given empirical meaningfulness only when the system is given some empirical interpretation" via the translation of some of the theoretical statements into observational language (Caldwell 1982, 25). It is usually the "lower level" deduced consequences of a theory that will describe observables and that are subject to empirical verification. Friedman's version of instrumentalism is much less formal and simply focuses attention on the testing of a theory's predictions with no attention being given to the realism of assumptions. Both positions, however, provided a view of science that could counter institutionalist demands for realism. Both gave wide range to deductive theorizing with the emphasis only on the empirical testing (by verification or falsification) of some specific implications of the theoretical model. This gradually displaced the broader institutionalist concern with realism. ${ }^{11}$

Logical empiricism, in addition, claimed to be a general description of scientific procedure, applicable to both the natural and physical sciences, and it largely displaced pragmatism as the ruling philosophy of science in the United States. Once neoclassical and Keynesian theory had an empirical component, they could claim the mantel of science while at the same time accusing institutionalists of naïve empiricism. All of the criticism of institutionalism as descriptive, lacking theory, or antitheoretical either explicitly or implicitly adopts one of these views of what constitutes a "scientific economics".

\section{CONCLUSION}

This paper argues that the ideas of "science" and "social control" were central ideas in the formation of institutional economics in the interwar period. This is not the usual presentation of institutionalism, but it is one that is in line with the way in which those most closely involved in the formation of the institutionalist movement defined it themselves. These ideas, perhaps more than any others, defined the movement and its central aims of critical investigation of the functioning of the economic order and its "intelligent guidance" in order to better meet the social or public interest. The rhetoric of science and social control is to be found everywhere in the institutionalist literature of the 1920s and 1930s. In the definition of science, in the idea of social control, and in the links between them, institutionalists drew heavily on the philosophy of John Dewey.

\footnotetext{
${ }^{11}$ This did not happen in all areas of the discipline at the same pace. Labor economics, for example, remained quite empirical and institutional for some time.
} 
These ideas also provided the points of connection between the institutionalist movement, other social scientists and legal realists, and the foundations that provided financial support. These connections led directly to the ability of institutionalists to further their research agendas through organizations such as the NBER, Brookings, and the SSRC.

The decline of the position of institutionalism in the post 1945 period can also be connected to these central ideas, but in a different way. Keynes and Keynesian economics and the related programs of reform associated with the welfare state took away the particular institutionalist association with the rejection of laissez-faire and the promotion of programs of "social control". The arrival of positivistic ideas of science also displaced the pragmatic ideas embedded in institutionalism and provided new "scientific" justifications of the deductive and abstract methods rejected by institutionalists. The accepted idea of what constituted scientific economics changed dramatically and in directions damaging to the more empirical approaches associated with institutionalism. Institutionalists found themselves no longer able to claim to be more scientific or better at developing effective instruments for social control than their Keynesian or more orthodox competitors.

\section{REFERENCES}

Biddle, Jeff. 1998. Social science and the making of social policy: Wesley Mitchell's Vision. In The economic mind in America: essays in the history of American economics, ed. Malcolm Rutherford. London: Routledge, 43-79.

Bulmer, Martin, and Joan Bulmer. 1981. Philanthropy and social science in the 1920s: Beardsley Ruml and the Laura Spelman Rockefeller Memorial, 1922-1929. Minerva 19 (3): 347-407.

Caldwell, Bruce J. 1982. Beyond positivism: economic methodology in the twentieth century. London: George Allen and Unwin.

Clark, John M. 1919. Economic theory in an era of social readjustment. American Economic Review, 9 (1): 280-290.

Clark, John M. 1923. Studies in the economics of overhead costs. Chicago: University of Chicago Press.

Clark, John M. 1926. Social control of business. Chicago: University of Chicago Press.

Clark, John M. 1927. Recent developments in economics. In Recent developments in the social sciences, ed. Edward C. Hayes. Philadelphia: Lippencott, 213-306.

Clark, John M. 1935. Economics of planning public works. Washington D.C.: US Government Printing Office.

Clark, John M. 1942. Economic adjustment after war: the theoretical issues. American Economic Review, 32 (Supplement): 1-12. 
Clark, John M. 1971 [1924]. The socializing of theoretical economics. In The trend of economics, ed. Rexford G. Tugwell. Port Washington (NY): Kennikat Press, 73-102.

Committee on Recent Economic Changes. 1929. Recent economic changes in the United States. New York: McGraw-Hill.

Copeland, Morris. 1929. Two hypotheses concerning the equation of exchange. Journal of the American Statistical Association, 24 (Supplement): 146-148.

Craver, Earlene, and Axel Leijonhufvud. 1987. Economics in America: the continental influence. History of Political Economy, 19 (2): 173-182.

Dewey, John. 1929. The quest for certainty. New York: Minton, Balch \& Co. Gifrord Lectures.

Edie, Lionel D. 1926. Economics: principles and problems. New York: Thomas Y. Crowell Company.

Edie, Lionel D. 1927. Some positive contributions of the institutional concept. Quarterly Journal of Economics, 41 (3): 405-440.

Everett, Helen. 1931. Social control. Encyclopaedia of the social sciences, vol. 4. New York: Macmillan, 344-349.

Fisher, Donald. 1993. Fundamental development of the social sciences: Rockefeller philanthropy and the United States Social Science Research Council. Ann Arbor (MI): University of Michigan Press.

Frank, Lawrence K. 1923. The status of social sciences in the United Sates. Rockefeller Archive Center, Laura Spelman Rockefeller Memorial, Series 3.6, Box 63, Folder 679.

Fried, Barbara H. 1998. The progressive assault on laissez faire: Robert Hale and the first law and economics movement. Cambridge (MA): Harvard University Press.

Friedman, Milton. 1953. The methodology of positive economics. In Essays in positive economics, Milton Friedman. Chicago: University of Chicago Press, 3-43.

Giddings. Franklin H. 1902. Review of E. A. Ross's Social control. Annals of the American Academy of Political and Social Science, 19 (3): 136-141.

Ginzberg, Eli. 1997. Wesley Clair Mitchell. History of Political Economy, 29 (3): 371-390.

Hagemann, Harald. 2005. Dismissal, expulsion, and emigration of German-speaking economists after 1933. Journal of the History of Economic Thought, 27 (4): 405420.

Hamilton, Walton H. (n.d.a). Control of industrial development. Walton Hamilton Papers, Box J4, Folder 6.

Hamilton, Walton H. (n.d.b). The control of industry. Walton Hamilton Papers, Box J3, Folder 3.

Hamilton, Walton H. 1919. The institutional approach to economic theory. American Economic Review, 9 (Supplement): 309-318.

Hamilton, Walton H. 1926. Report to the Board of Trustees, The Robert Brookings Graduate School of Economics and Government, April 30, 1926. Appendix 3 to Harold G. Moulton, The history of the organization of the Brookings Institution, June 1928. Brookings Institution Archives, Item 17, Formal and informal histories of the Brookings Institution, 1928-1966, Box 1, File: Memoranda on the early history of the Brookings Institution. 
Hamilton, Walton H. 1930. Affectation with public interest. Yale Law Journal, 39 (8): 1089-1112.

Hamilton, Walton H. 1937. The living law. Survey Graphic, 26 (December): 632-635, 735.

Hamilton, Walton H., and Stacy May. 1968 [1923]. The control of wages. New York: Augustus M. Kelley.

Hamilton, Walton H., and Helen R. Wright. 1925. The case of bituminous coal. New York: Macmillan.

Hands, D. Wade. 2004. On operationalism in economics. Journal of Economic Issues, 38 (4): 953-968.

Harris, Seymour E. (ed.). 1948. The new economics. New York: Alfred A. Knopf.

Keezer, Dexter M., and Stacy May. 1930. The public control of business. New York: Harper.

Knight, Frank H. 1935 [1924]. The limitations of scientific method in economics. Reprinted in The ethics of competition and other essays. Chicago: University of Chicago Press.

Koopmans, Tjalling C. 1947. Measurement without theory. Review of Economic Statistics, 29 (3): 161-172.

Mills, Frederick, C. 1971 [1924]. On measurement in economics. In The trend of economics, ed. Rexford G. Tugwell. Port Washington (NY): Kennikat Press, 37-70.

Mitchell, Wesley C. 1913. Business cycles. Berkeley: University of California Press.

Mitchell, Wesley C. 1925. Quantitative analysis in economic theory. American Economic Review, 15 (1): 1-12.

Mitchell, Wesley C. 1936 [1928]. Letter from Wesley C. Mitchell to John M. Clark. In Preface to social economics, John M. Clark. New York: Farrar and Rinehart, 410-416.

Mitchell, Wesley C. 1950 [1936]. Intelligence and the guidance of economic evolution. Reprinted in The backward art of spending money. New York: Augustus M. Kelley, 103-136.

Mongiovi, Gary. 2005. Émigré economists and American neoclassical economics, 19331945. Journal of the History of Economic Thought, 27 (4): 427-437.

Ross, Dorothy. 1991. The origins of American social science. Cambridge: Cambridge University Press.

Ross, Edward A. 1901. Social control: a survey on the foundations of order. New York: The Macmillan Company.

Ruml, Beardsley. 1922. General memorandum by the Director, October 1922. Rockefeller Archive Centre, Laura Spelman Rockefeller Memorial, Series 2, Box 2, Folder 31.

Rutherford, Malcolm. 1987. Wesley Mitchell: institutions and quantitative methods. Eastern Economic Journal, 13 (1): 63-73.

Rutherford, Malcolm. 1999. Institutionalism as "scientific" economics. In From classical economics to the theory of the firm: essays in honour of D. P. O'Brien, eds. Roger Backhouse, and John Creedy. Aldershot (UK): Edward Elgar Publishing.

Rutherford, Malcolm. 2000. Understanding institutional economics: 1918-1929. Journal of the History of Economic Thought, 22 (3): 277-308.

Rutherford, Malcolm. 2004. Institutional economics at Columbia University. History of Political Economy, 36 (1): 31-78. 
Rutherford, Malcolm. 2005a. Who's afraid of Arthur Burns? The NBER and the Foundations. Journal of the History of Economic Thought, 27 (2): 109-139.

Rutherford, Malcolm. 2005b. Walton H. Hamilton and the public control of business. In The role of government in the history of political economy, eds. Steven Medema, and Peter Boettke. History of Political Economy, 37 (Supplement), Durham (NC): Duke University Press, 234-273.

Rutherford, Malcolm and Tyler DesRoches. 2008. The institutionalist reaction to Keynesian economics. Journal of the History of Economic Thought, 30 (1): 29-48.

Scherer, F. M. 2000. The emigration of German-speaking economists after 1933. Journal of Economic Literature, 38 (3): 614-626.

Slichter, Sumner H. 1971 [1924]. The organization and control of economic activity. In The trend of economics, ed. Rexford G. Tugwell. Port Washington (NY): Kennikat Press, 303-355.

Soule, George. 1971 [1924]. Economics: science and art. In The trend of economics, ed. Rexford G. Tugwell. Port Washington (NY): Kennikat Press, 359-367.

Stewart, Walter W. 1919. Economic theory: discussion. American Economic Review, 9 (March): 319-320.

Tugwell, Rexford G. 1968 [1922]. The economic basis of public interest. New York: Agustus M. Kelley.

Tugwell, Rexford G. 1971 [1924]. Experimental economics. In The trend of economics, ed. Rexford G. Tugwell. Port Washington (NY): Kennikat Press, 370-422.

Tugwell, Rexford G. 1982. To the lesser heights of Morningside: a memoir. Philadelphia: University of Pennsylvania Press.

Viner, Jacob. 1928. The present status and future prospects of quantitative economics. American Economic Review, 18 (Supplement): 30-36.

Weinberg, Julius, Gisela J. Hinkle, and Roscoe C. Hinkle. 1969. Introduction. In Social control: a survey on the foundations of order, Edward A. Ross. Cleveland: Press of Case Western Reserve University.

Wolfe, Albert B. 1971 [1924]. Functional economics. In The trend of economics, ed. Rexford G. Tugwell. Port Washington (NY): Kennikat Press, 443-482.

Wolman, Leo. 1927. The frontiers of social control. American Labor Legislation Review 17: 233-241.

Yonay, Yuval P. 1998. The struggle over the soul of economics: institutionalist and neoclassical economists in America between the Wars. Princeton (NJ): Princeton University Press.

Malcolm Rutherford is professor of economics at the University of Victoria, British Columbia, Canada. He has published widely on the history of American institutional economics in journals such as History of Political Economy, Journal of the History of Economic Thought, European Journal of History of Economic Thought, Journal of Economic Issues, and the Journal of Economic Perspectives. He is the author of Institutions in economics: the old and the new institutionalism (Cambridge University Press, 1994). His latest book, The institutionalist movement in 
RUTHERFORD / THE INSTITUTIONALIST MOVEMENT IN AMERICAN ECONOMICS

American economics, 1918-1947: science and social control, will be published by Cambridge University Press in 2011.

Contact e-mail: <rutherfo@uvic.ca>

Website: <http://web.uvic.ca/ rutherfo/mr_home.html> 